\title{
On the occurrence and distribution of Calanipeda aquaedulcis Kritschagin, 1873 (Copepoda, Calanoida, Pseudodiaptomidae) in Sicily, Italy, with some notes on coexistence and species replacement in calanoid copepods
}

\author{
Luca Vecchioni, Federico Marrone, Luigi Naselli-Flores \\ Department of Biological, Chemical and Pharmaceutical Sciences and Technologies, University of Palermo, via Archirafi 18, 90123 \\ Palermo, Italy
}

\begin{abstract}
The only population of the pseudodiaptomid copepod Calanipeda aquaedulcis Kritschagin, 1873 to date reported to occur in Sicily disappeared at the beginning of the XXI century due to deep environmental changes which affected the single site (Lake Biviere di Gela) known for this species on the island. In that site C. aquaedulcis is now replaced by Copidodiaptomus numidicus (Gurney, 1909), a diaptomid copepod whose distribution has been greatly increasing since the second half of the last century. In the present note, the occurrence of $C$. aquaedulcis in 12 novel water bodies spread throughout Sicily is reported, and some environmental data on the sites where the species was collected are provided. Moreover, in a few sites $C$. aquaedulcis was found to co-occur with Copidodiaptomus numidicus. The recorded co-occurrence of these two species and the replacement of $C$. aquaedulcis with C. numidicus in Lake Biviere di Gela are briefly discussed.
\end{abstract}

\section{INTRODUCTION}

Hydrological alterations can deeply modify the biotic composition of aquatic ecosystems (Richter et al., 1996). This is particularly true in those water bodies used to fulfil agriculture needs and located in semi-arid regions (NaselliFlores, 2003). The extent of these operational procedures can be strong enough to cause a significant reduction in the stored volumes (Jeppesen et al., 2015) and, in some cases, the complete drying out of shallow lakes and wetlands. As a consequence of volume loss, water bodies can experience deep changes in their chemical and physical characteristics; local extinction of taxa and changes in the biological structure of aquatic communities due to species replacements may therefore occur.

Calanipeda aquaedulcis is the only pseudodiaptomid copepod occurring in the inland waters of the West Palearctic biogeographical region, and the only species of the monotypic genus Calanipeda Kritschagin, 1873 (Dussart and Defaye 2002). This widespread copepod is known to occur from the circum-Mediterranean area to the Black and Caspian seas regions, where it occurs mostly in brackish, coastal, large water bodies (Błędzki and Rybak 2016), although it is also known to occur in freshwater lakes (Marrone et al., 2019). In Italy, C. aquaedulcis is reported for several localities throughout the country (see Cannicci 1939; Stella 1984; Ruffo and Stoch 2005; Belmonte, 2018); conversely, a single population was to date reported for Sicily: the one occurring in the shallow Lake Biviere di Gela (Stella 1979, 1984; Margaritora et al., 1982; Calvo et al., 1993; Ruffo and Stoch 2005). At the end of the XX century, the lake, located at $1.3 \mathrm{~km}$ from the southern Sicilian coast and $8 \mathrm{~m}$ asl, underwent a period of severe water reduction which caused the intrusion of seawater with a consequent increase in its conductivity values (Jeppesen et al., 2015). These events caused the disappearing of aquatic macrophytes and the recurrent massive development of the toxin-producing haptophyte Prymnesium parvum Carter (Naselli-Flores and Barone, 2019), known to be detrimental for other planktonic organisms due to its toxins (Fistarol et al., 2003). These blooms deeply changed the biological structure of the lake, and Barone et al. (2010) recorded the extinction of the crustacean zooplankton inhabiting the lake, which likely occurred during the first blooms of P. parvum. Among those species, the only known Sicilian population of Calanipeda aquaedulcis had vanished (Calvo et al. 1993 and literature therein).

In this paper, we present some selected results from an extensive sampling campaign conducted on both temporary and permanent water bodies throughout Sicily. This allowed checking whether additional populations of the species were present on the island or if Calanipeda aquaedulcis should be considered locally extinct.

\section{METHODS}

Samples were collected from 2003 to 2019 in more than 700 water bodies spread throughout mainland Sicily (F. Marrone, unpublished data). Permanent and temporary natural ponds and swamps, agriculture artificial ponds, and larger dam-reservoirs were sampled. The latter ecosystem type had already been sampled in $1987 / 88$ by Calvo et al. (1993). Some of the samples collected by these last authors are still available at the University of Palermo and were therefore re-analyzed to check eventual differences in the species composition with the more recently collected samples.

In each visited water body, water temperature and 
electric conductivity at $20^{\circ} \mathrm{C}$ were measured with a Hanna Instruments HI9835 multiprobe. Due to the small dimensions of the majority of sampled sites, plankton was collected from the shoreline with a 125 micron meshsized plankton net; in the largest water bodies, vertical plankton hauls were also performed from a boat in the middle of the lake.

Collected samples were fixed in situ in $80 \%$ ethanol; calanoid copepods were sorted in the laboratory and identified to species level according to Kiefer (1978) and Stella (1984). All the samples are stored at the University of Palermo, Italy, in the crustacean collection of FM.

\section{RESULTS}

In twelve out of the 728 sampled water bodies, populations of Calanipeda aquaedulcis were found (Tab. 1, Fig. 1). The species was also present in the zooplankton samples collected by Calvo et al. (1993) on $4^{\text {th }}$ September and $2^{\text {nd }}$ December 1987 in Lake Disueri (CL024), although the presence of this species, likely by mistake, was not included in the checklist of the zooplankton of the lake provided by these authors. Conversely, in the sample collected in the same lake on $10^{\text {th }}$ April 2019 by the authors of the present note, no calanoid copepods were present. In Lake Cimia (CL027), where the presence of the diaptomid Copidodiaptomus numidicus had been reported by Calvo et al. (1993), the co-existence of $C$. aquaedulcis and $C$. numidicus was observed on $10^{\text {th }}$ April 2019 (Tab. 1).

Although when present Calanipeda aquaedulcis was, in the majority of cases, the only calanoid copepod recorded, it synchronically co-occurred with Copidodiaptomus numidicus in four sites (Tab. 1). These two species were generally co-occurring at conductivity values below $5 \mathrm{mS}$ $\mathrm{cm}^{-1}$ (CL024, CL027, CL028 and EN004), even though in a single site (CL028, a farm pond close to Lake Cimia, filled with waters from that lake) both species were present at conductivity values above $14 \mathrm{mS} \mathrm{cm}{ }^{-1}$. The sites with $C$. aquaedulcis as the only calanoid species were a few brackish coastal waterbodies (TP107, TP114, TP132, TP133, TP134 and TP165) located on the western coast of Sicily and characterized by conductivity values above $11 \mathrm{mS} \mathrm{cm}^{-1}$ due to seawater intrusions. In addition, it was the only calanoid species in a brackish coastal swamp (SR022) by the Ionian Sea (conductivity above $3 \mathrm{mS} \mathrm{cm}^{-1}$ ), and in the Lake Biviere di Lentini (SR011), a dam reservoir filled in the mid of the ' 90 s of the last century and characterized by conductivity values ranging between 1.3 and $1.7 \mathrm{mS} \mathrm{cm}^{-1}$.

\section{DISCUSSION}

Human disturbance and the building of artificial water bodies are known to have significant effects on

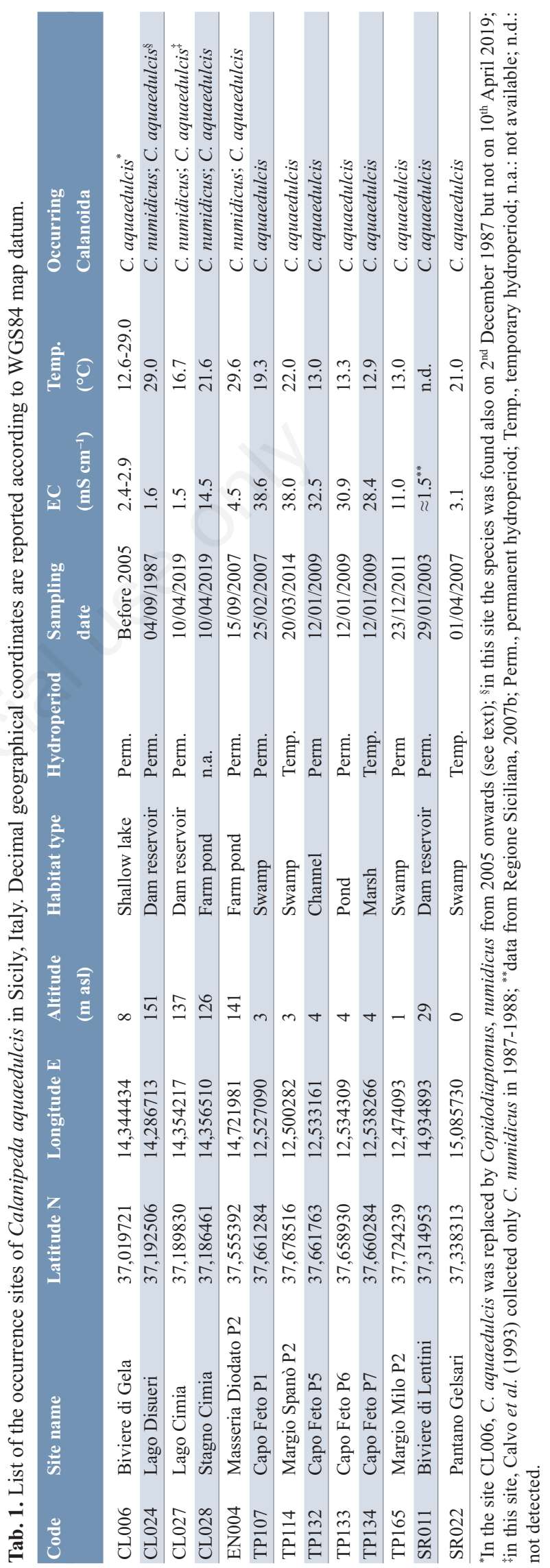


species distribution, favoring the spreading and establishment of the more euryecious species at the expense of the more stenoecious ones (Miracle, 1982; Parkes and Duggan, 2012; Riley et al., 2018). Such a process leads to an alteration of the original distribution patterns, to the homogenization of faunas at a regional and global scale (Rahel, 2002), and to the regression or extinction of the native communities, which are often of great biogeographic and conservation value (e.g. the "Hemidiaptomus ponds", sensu Sahuquillo and Miracle, 2013). Moreover, water movements among different water bodies due to management procedures commonly occur in semi-arid areas (Marrone and Naselli-Flores, 2019 , in press). These are often drastic and unpredictable, and do not keep in any account the alterations they can cause on the structure of biological communities (Naselli-Flores, 1999). The stress caused by humandriven operational procedures in man-made lakes can eventually lead to local extinction of species and contribute to weaken those biological filters which act as a barrier against the colonization of new species (Incagnone et al., 2015). Local species extinction can open the way to more euryecious taxa, and eventually to invasive species.

In accordance to what reported by Barone et al. (2010) and Naselli-Flores (unpublished data), Calanipeda aquaedulcis was not found in the samples collected in lake Biviere di Gela from 2003 onward (until April 2019);

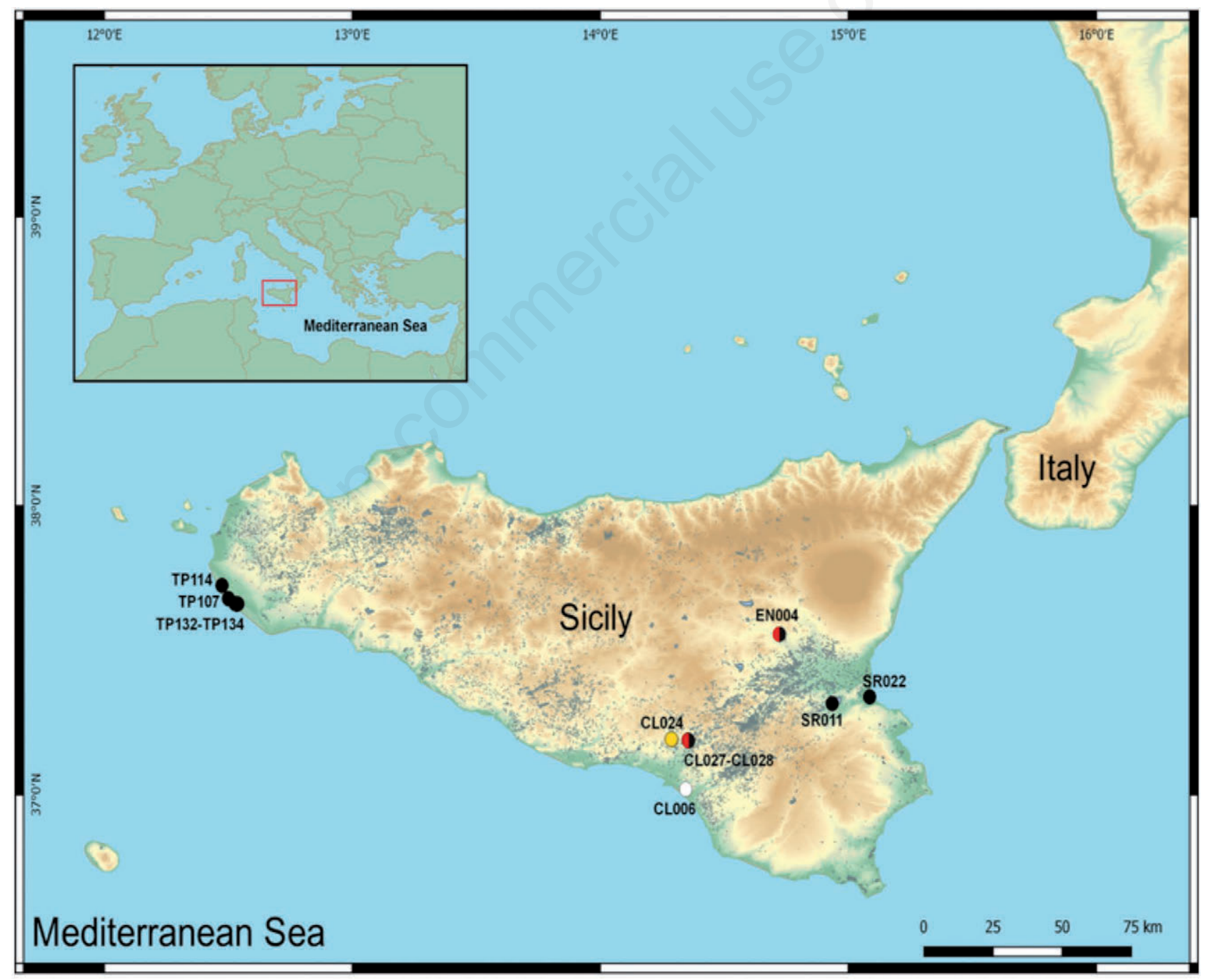

Fig. 1. Occurrence localities of Calanipeda aquaedulcis in Sicily. Black circles, occurrence of C. aquaedulcis; black-and-red circles, co-existence of C. aquaedulcis and Copidodiaptomus numidicus; Wwhite circle, previous presence of C. aquaedulcis, now replaced by C. numidicus; yellow circle, co-occurrence of C. aquaedulcis and C. numidicus in 1987, no calanoids species in 2019. 
in this lake, C. aquaedulcis is now replaced by the euryecious diaptomid copepod Copidodiaptomus numidicus, which was first detected in 2005. The disappearing of C. aquaedulcis from Lake Biviere di Gela likely occurred at the end of the last century when the lake depth reached values ranging between 1.2 and $1.5 \mathrm{~m}$ due to the intensification of water demand for irrigation purposes (Jeppesen et al., 2015). This decrease in water levels caused drastic changes in the chemical, physical and biological features of the lake, which allowed the establishment of the toxic haptophyte Prymnesium parvum, and made this environment unsuitable for the pseudodiaptomid (for more details see Barone et al., 2010; Jeppesen et al., 2015).

The re-analysis of some of the samples collected by Calvo et al. (1993) revealed that Calanipeda aquaedulcis was present with low numbers in Lake Disueri in the ' $80 \mathrm{~s}$, whereas the species was not observed in the samples collected in the same lake in spring 2019. Lake Disueri is a dam reservoir located 20 $\mathrm{km}$ North West of Lake Biviere di Gela. The lake, since the mid 1990s, has been connected by a pipeline to Lake Cimia to fulfill irrigation needs. Actually, although both the lakes were built in the catchment of Gela River, they rest on two parallel river stretches. These merge downstream both the dams, before flowing into the Sicilian Channel, about $8 \mathrm{~km}$ from the Lake Biviere di Gela. All these lakes have conductivity values higher than $1.5 \mathrm{mS} \mathrm{cm}^{-1}$ and show chloride-sulphate-alkalineearth waters, even though the chemical characteristics of Lake Biviere di Gela are due to the intrusions of seawater (Barone et al., 2010) whereas those of Lake Disueri and Lake Cimia are due to the outcrops of evaporites in their catchment (Calvo et al., 1993). At the end of the 1980s, the capacity of Lake Disueri had already been drastically reduced by siltation (Calvo et al., 1993), and in 2006 the lake was completely dried out in order to carry out dam maintenance (Regione Siciliana, 2007a). The absence of calanoid copepods in the samples collected on April 10 $10^{\text {th }}, 2019$ in Lake Disueri is probably to be ascribed to the several episodes of total desiccation the lake underwent in the past years, which likely caused a re-arrangement of its biological structure. At the same time, the pipeline connecting Lake Disueri to Lake Cimia may have favored the dispersal of $C$. aquaedulcis in the latter water body and, from there, in the agriculture pond fed with Lake Cimia's waters.

In spite of the extinction of the population inhabiting the lake Biviere di Gela, Calanipeda aquaedulcis proved to be a rather infrequent but widespread species in Sicily. In good accordance with the available literature, most of its occurrence localities are permanent, coastal, brackish water bodies. Nevertheless, the species was also collected in temporary ponds and swamps (e.g. SR022, TP114, and TP134), and even in man-made reservoirs located in the Sicilian hinterland (e.g. SR011, EN004, CL024, CL027 and CL028). These latter sites, which are located up to $33 \mathrm{~km}$ far from the seashores and up to 151 $\mathrm{m}$ above sea level, are characterized by significantly mineralized but atalassohaline waters, further stressing the euryecious character of the species. In fact, as already highlighted by Cannicci (1939) and Borutzky et al. (1991), C. aquaedulcis seems to be an euryhaline species thriving in poorly mineralized to isohaline waters, and its occurrence in hypersaline water bodies is to be considered only sporadic.

Even though Gonçalves et al. (2012) reported the coexistence of $C$. numidicus and $C$. aquaedulcis in the River Mondego (Portugal), where they could be possibly part of the biological drift, the synchronic co-occurrence of adult stages of $C$. aquaedulcis and C. numidicus in lentic water bodies is to our knowledge unprecedented. It would be therefore worth investigating the phenology of these assemblages to check whether the two species can co-exist in the long term or are rather experiencing a process of species replacement as already observed in Lake Biviere di Gela.

\section{CONCLUSIONS}

The sampling campaign carried out in Sicilian inland waters so far has shown that, although sound synoptic data are available for some taxonomical groups (e.g. diaptomids, see Marrone et al., 2017), the biodiversity assessment of Mediterranean aquatic ecosystems is still far from being complete. Several circum-Mediterranean regions have not been adequately investigated yet, as well as many large islands in the Mediterranean Basin (Ruffo and Stoch, 2005; Marrone, 2006). This makes difficult to assess the actual biodiversity of Mediterranean inland waters, the appreciation of its value, and the zoogeographical relationships existing among the different faunas. At the same time, the disappearance of rare aquatic species and the spreading of alien, invasive ones can be overlooked due the paucity or lack of information (Marrone and Naselli-Flores, 2015), further increasing the threats to which these ecosystems are subjected.

Finally, in the light of the wide distribution of $C$. aquaedulcis and of the frequent cryptic speciation in all the calanoid copepod families (Marrone et al., 2013; Cornils and Held 2014; Sabia et al., 2017; Kasapidis et al., 2018, and references therein), the carrying out of a phylogeographic study of the species throughout its known distribution range is desirable. 


\section{Corresponding author: federico.marrone@unipa.it}

Keywords: Crustacea; zooplankton local extinction; species replacement; Mediterranean basin.

Conflict of interest: The authors declare no competing interests.

Ethical statement: This article does not contain any studies with human participants or animals performed by any of the authors.

Received: 15 March 2019.

Accepted: 21 May 2019.

This work is licensed under a Creative Commons Attribution NonCommercial 4.0 License (CC BY-NC 4.0).

${ }^{\circ}$ Copyright: the Author(s), 2019

Licensee PAGEPress, Italy

Advances in Oceanography and Limnology, 2019; 10:8177

DOI: 10.4081/aiol.2019.8177

\section{REFERENCES}

Barone R, Castelli G, Naselli-Flores L, 2010. Red sky at night cyanobacteria delight: the role of climate in structuring phytoplankton assemblage in a shallow, Mediterranean lake (Biviere di Gela, southeastern Sicily). Hydrobiologia 639:43-53.

Belmonte G, 2018. Calanoida (Crustacea: Copepoda) of the Italian fauna: a review. Eur. Zool. J. 85:274-290.

Błędzki LA, Rybak JI, 2016. Freshwater crustacean zooplankton of Europe. Springer, Switzerland: 923 pp.

Borutzky EB, Stepanova LA, Kos MS, 1991. Opredelitel' Calanoida presnykh vod SSSR (Key to the Fresh-water Calanoids of the URSS). Nauka, St. Petersburg: 504 pp.

Calvo S, Barone R, Naselli-Flores L, Fradà Orestano C, Dongarrà G, Lugaro A, Genchi, G, 1993. Limnological studies on lakes and reservoirs of Sicily. Nat. Sicil. 27(Suppl.):1-292.

Cannicci G, 1939. Sulla distribuzione della Popella guernei Richard (Calanipeda aquae dulcis Kritz.) negli stagni salmastri. Int. Rev. Hydrobiol. 38:489-503.

Dussart B, Defaye D, 2002. World Directory of Crustacea Copepoda of Inland Waters, I. Calaniformes. Backhuys Publisher, Leiden: 276 pp.

Fistarol G, Legrand C, Granéli E, 2003. Allelopathic effects of Prymnesium parvum on a natural plankton community. Mar. Ecol. Prog. Ser. 255:115-125.

Gonçalves AMM, Azeiteiro UM, Pardal MA, De Troch M, 2012. Fatty acid profiling reveals seasonal and spatial shifts in zooplankton diet in a temperate estuary. Estuar. Coast. Shelf. Sci. 109:70-80.

Jeppesen E, Brucet S, Naselli-Flores L, Papastergiadou E, Stefanidis K, Nõges T, Nõges P, Attayde JL, Zohary T, Coppens J, Bucak T, Fernandes Menezes F, Sousa Freitas FR, Kernan M, Søndergaard M, Beklioğlu M, 2015. Ecological impacts of global warming and water abstraction on lakes and reservoirs due to changes in water level and related changes in salinity. Hydrobiologia 750:201-227.
Kasapidis P, Siokou I, Khelifi-Touhami M, Mazzocchi MG, Matthaiaki M, Christou E, Fernandez de Puelles ML, Gubanova A, Di Capua I, Batziakas S, Frangoulis C, 2018. Revising the taxonomic status and distribution of the Paracalanus parvus species complex (Copepoda, Calanoida) in the Mediterranean and Black Seas through an integrated analysis of morphology and molecular taxonomy. J. Plankton Res. 40:595-605.

Kiefer F, 1978. [Das Zooplankton der Binnengewässer. Freilebende Copepoda. Die Binnengewässer, Band 26 Teil 2].[Book in German]. E. Schweizerbart'sche Verlagbuchhandlung, Stuttgart: 343 pp.

Margaritora FG, Mastrantuono L, Crosetti D, Lombardi F, 1982. Contributo alla conoscenza della fauna ad entomostraci delle acque interne della Sicilia. Animalia 9:87-102.

Marrone F, 2006. The microcrustacean fauna of Sicily and the central Mediterrranean Sea area - Current knowledge and gaps to be filled. Pol. J. Ecol. 54:681-685.

Marrone F, Alfonso G, Naselli-Flores L, Stoch, F, 2017. Diversity patterns and biogeography of Diaptomidae (Copepoda, Calanoida) in the Western Palearctic. Hydrobiologia 800:45-60.

Marrone F, Alfonso G, Stoch F, Pieri V, Alonso M, Dretakis M, Naselli-Flores L, 2019. An account on the nonmalacostracan crustacean fauna from the inland waters of Crete, Greece, with the synonymization of Arctodiaptomus piliger Brehm, 1955 with Arctodiaptomus alpinus (Imhof, 1885). Limnetica 38:167-187.

Marrone F, Lo Brutto S, Hundsdoerfer AK, Arculeo M, 2013. Overlooked cryptic endemism in copepods: systematics and natural history of the calanoid subgenus Occidodiaptomus Borutzky 1991 (Copepoda, Calanoida, Diaptomidae). Mol. Phylogenet. Evol. 66:190-202.

Marrone F, Naselli-Flores L, 2015. A review on the animal xenodiversity in Sicilian inland waters (Italy). Adv. Oceanogr. Limnol. 6:2-12.

Marrone F, Naselli-Flores L (2019). Different invasibility of permanent and temporary water bodies in a semi-arid Mediterranean island. Inland Waters (In Press).

Miracle MR, 1982. Biogeography of freshwater zooplanktonic communities of Spain. J. Biogeog. 9:455-467.

Naselli-Flores L, 1999. Limnological aspects of Sicilian reservoirs: a comparative, ecosystemic approach, p. 283-311. In: J.G. Tundisi and M. Straškraba (eds.), Theoretical reservoir ecology and its applications. Backhuys Publishers, Leiden.

Naselli-Flores L, 2003. Man-made lakes in Mediterranean semiarid climate: the strange case of Dr Deep Lake and $\mathrm{Mr}$ Shallow Lake. Hydrobiologia 506-509: 13-21.

Naselli-Flores L, Barone R, 2019. Mixotrophic phytoplankton dynamics in a shallow Mediterranean water body: how to make a virtue out of necessity. Hydrobiologia 831:33-41.

Parkes SM, Duggan IC, 2012. Are zooplankton invasions in constructed waters facilitated by simple communities? Divers. Distrib. 18:1199-1210.

Rahel F, 2002. Homogenization of freshwater faunas. Annu. Rev. Ecol. Syst. 33:291-315.

Regione Siciliana, 2007a. [Piano di tutela delle acque della Sicilia. Bacino Idrografico Gela (R19077)].[in Italian]. SOGESID, Palermo. Accessed on: April 21, 2019. Available from: http://www.osservatorioacque.it/documenti/pta/b26.pdf 
Regione Siciliana, 2007b. Piano di tutela delle acque della Sicilia. Bacino Idrografico Lentini e bacini minori tra Lentini e Simeto (R19093].[in Italian]. SOGESID, Palermo. Accessed on: April 21, 2019. Available from: http://www.osservatorioacque.it/documenti/pta/b36.pdf

Richter BD, Baumgartner JV, Powell J, Braun DP, 1996. A method for assessing hydrological alteration within ecosystems. Conserv. Biol. 10:1163-1174.

Riley WD, Potter ECE, Biggs J, Collins AL, Jarvie HP, Jones JI, Kelly-Quinn M, Ormerod SJ, Sear DA, Wilby RL, Broadmeadow S, Brown CD, Chanin P, Copp GH, Cowx IG, Grogan A, Hornby DD, Huggett D, Kelly MG, Naura M, Newman JR, Siriwardenat GM. 2018. Small water bodies in Great Britain and Ireland: Ecosystem function, human-generated degradation, and options for restorative action. Sci. Total. Environ. 645:1598-1616.
Ruffo S, Stoch F, 2005. [Checklist e distribuzione della fauna italiana].[Article in Italian]. Mem. Mus. Civico Storia Nat. Verona, 2 Ser., Sez. Sci. Vita 16:1-307.

Sabia L, Di Capua I, Percopo I, Uttieri M, Amato A, 2017. ITS2 in calanoid copepods: reconstructing phylogenetic relationships and identifying a newly introduced species in the Mediterranean. Eur. Zool. J. 84:104-115.

Sahuquillo M, Miracle MR, 2013. The role of historic and climatic factors in the distribution of crustacean communities in Iberian Mediterranean ponds. Freshwater Biol. 58:1251-1266.

Stella E, 1979. [Nuovi reperti di calanidi (Crustacea Copepoda) in Italia].[Article in Italian]. Boll. Mus. Civico Storia Nat. Verona. 6:333-346.

Stella E, 1984. [Copepoda: Calanoida. XXI Fauna d'Italia]. [Book in Italian]. Ed. Calderini, Bologna: 101 pp. 